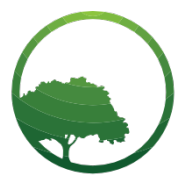

Research in Business \& Social Science

IJRBS VOL 8 NO 6 ISSN: 2147-4478

\title{
Effect of learning goal orientation on leadership development
}

\author{
Emmanuel Mango*, Jeremiah Koshal ${ }^{b}$, Caren Ouma ${ }^{c}$ \\ ${ }^{a, b, c}$ Chandaria School of Business, United States International University-Africa, Nairobi, Kenya
}

Crossref

\begin{tabular}{l} 
A R T I C L E IN F O \\
\hline Article history: \\
Received 04 August 2019 \\
Received in revis. form 19 Aug. 2019 \\
Accepted 22 August 2019 \\
\hline Keywords: \\
Leadership development \\
Learning goal orientation \\
Leadership \\
Leader developmental readiness \\
JEL Classification: \\
O15 \\
P36
\end{tabular}

\begin{abstract}
A B S T R A C T
The study examines the effect of learning goal orientation on leadership development. The study was conducted among 288 MBA students within private universities in Kenya. Data was collected through self-administered questionnaires and correlation, one-way ANOVA and regression analyses were performed in Statistical Package for the Social Sciences version 23. The study reveals that learning goal orientation has a significant effect on leadership development, $F(1,286)=62.346, p<001$. In addition, learning goal orientation accounts for $17.9 \%$ of the variation in leadership development. Thus, enhancing participants' learning goal orientation should be part and parcel of any leadership development program in order to improve the effectiveness of leadership development.
\end{abstract}

\section{Introduction}

Effective leadership development has eluded many organizations and academia for a long time. Why should anyone care if the current leadership development interventions are largely failing? Organizations are constantly searching for new and better ways to win in the competitive marketplace and the highly dynamic world. Effective leadership is the single most important element that organizations need in an ever changing world. Leadership provides direction, helps organizations to steer through the modern challenges and adapt as appropriately. Moreover, effective leaders mobilize, motivate and move both people and organizations to attain results that they couldn't have achieved on their own. Furthermore, effective leadership propels people and organizations through uncertain and turbulent times, and helps their teams to navigate through chaos, avoid stagnation and disintegration Also effective leadership contributes to psychological wellbeing of the employees and organizational safety climate. In addition, leadership promotes national development and the reverse is true, countries remain underdeveloped mainly due to ineffective leadership. Given the critical role that leaders play, every generation has experienced the problem of leadership shortage, but the current generation is in dire need of effective leadership. Deloitte Consulting LLP and Bersin [Deloitte] (2014) also observes that shortage of leaders is one of the biggest challenges for growth in companies around the world. Effective leadership development increases the numbers and the effectiveness of leaders and the reverse is true for ineffective leadership development.

Those who have attempted to improve the practice and study of leadership development focus on the same old elements of leadership development. The traditional elements of leadership development that have been studied and implemented previously include: the content of the leadership development programs, the delivery of leadership development programs, the length of the programs and advocating for leadership development programs that are entrenched in leadership theory. Despite numerous studies and implementation of the studies' findings on leadership development, there exists widespread dissatisfaction with leadership development outcomes. Some scholars have observed that leader developmental readiness may be the missing ingredient in

\footnotetext{
* Corresponding author. Tel: +254722888210 ORCID ID: 0000-0002-6638-0574

Peer review under responsibility of Bussecon International Academy.

(C) 2019 Bussecon International. Hosting by SSBFNET- Center for Strategic Studies in Business \& Finance. All rights reserved.

https://doi.org/10.20525/ijrbs.v8i6.459
} 
leadership development. Learning goal orientation is one of the five elements of leader developmental readiness, hence this study investigated the effect of learning goal orientation on leadership development. The study was conducted among 288 MBA students within private universities in Kenya. The study is made up of five sections: introduction, literature review, methodology, results and discussion and conclusion.

\section{Literature Review}

\section{Leadership Development}

Lack of effective leaders is largely attributable to ineffective leadership development (Muteswa, 2016; Eckert, Isaakyan \& Mulhern, 2014). Njue, Waiganjo and Kihoro (2016) argue that performance challenges experienced by the micro finance institutions in Kenya can be solved with effective leadership development. Monyoncho (2014) also argues that poor leadership development should be partly blamed for leadership failure in many nations. Despite the urgent need for well-developed leaders, about $75 \%$ of the highpotential programs are ineffective (Velayudhan, Gayatridevi, Benedict \& Devi, 2011; Development Dimensions International [DDI], 2015). In addition, Volz-Peacock, Carson and Marquardt (2016) observe that organizations around the world are struggling to develop leaders' capabilities. A survey by Deloitte (2014) revealed that only 13\% of the respondents were confident about their leadership development initiatives at all levels.

The pressing demand for effective leadership and rampant failure of current leadership development initiatives has led to urgent demand for better ways to develop leaders. A survey by Deloitte (2014) revealed that $86 \%$ of the respondents regard effective leadership development as urgent and important. The survey also revealed, one, the need to accelerate leadership development at all levels is one of the three key strategic areas for 2014 and beyond. Two, leadership development remains talent issue number one facing organizations around the world. Petrie (2014) faults the leadership development industry for not transiting into the 21st century, the present century is characterized by frequent changes, unfortunately the approaches to leadership development have relatively remained the same world over. The question is what is the missing ingredient in the current approaches to leadership development?

McCollum and Kajs (2007) argue that for one to succeed in leadership development, he/she must be motivated because motivation directs and maintains the necessary behaviour to accomplish the desired goal. Learning goal orientation is the aspect of motivation that influences people, in this case leaders, to desire to improve their leadership capacity and stay motived throughout the learning phase. Furthermore, learning orientation is a key success factor in leadership mentorship relationship (Kim, 2007).

Learning goal oriented individuals apply extra effort to gain knowledge and learn skills. They are also open and they welcome challenging tasks (Che-Ha, Mavondo \& Mohd-Said, 2014; Huang \& Luthans, 2015). The exertion of extra effort is critical for learners, McCollum and Kajs (2007), because leadership development is a demanding exercise given its scope and complexity. Learners with high learning goal orientation invest a lot of time and effort in tasks in order to develop competence, grow in knowledge and understanding, they have positive attitude towards learning and they attribute theirs success to effort and not ability (Montecinos, Madrid, Fernández \& Ahumada, 2014; McCollum \& Kajs, 2007; Dweck, 1986). Given the hypothesized contribution of learning goal orientation towards learning, this study sought to establish the effect it has on leadership development.

\section{Research and Methodology}

The study population was $\mathrm{N}=1,721$ MBA students within private chartered universities in Kenya. The study adopted stratified random sampling, while the sample size was determined scientifically by Aiken (1997), to be $n=314$. Learning goal orientation data was collected using a validated questionnaire developed by Button et al. (1996), while the data for leadership development and the respondents' demographics (age, gender, employment status, position, industry of employment, and years of work experience) was collected by instruments that were developed through extensive literature review and consultation with subject matter experts and was validated by first researcher in a pilot study. The learning goal orientation data was grouped into low and high learning goal orientation by use of the median. The analyses that were performed in the present study included: mean, correlation, One-Way ANOVA and linear regression.

\section{Result and Discussion}

\section{Results}

A response rate of 92 percent (288) was obtained. The respondents' age were distributed as follows: 21-30 years (53.47\%), 31-40 years $(34.72 \%)$ and $41-50$ years (11.81\%). $51.39 \%$ of the respondents were male, while $48.61 \%$ were female. The respondents' employment status were as follows: employed/self-employed at the time of data collection (79.17\%), employed/self-employed before but not at the time of data collection (15.28\%) and only 5.5\% had never been employed/self-employed. Positions of the respondents in their respective organizations were as follows: $62.5 \%$ were in managerial/leadership at the time of data collection, while only $37.5 \%$ were not. The results also revealed that $17.01 \%$ of the respondents worked for non-governmental organizations, $15.97 \%$ worked for government and $61.46 \%$ worked for corporates, while $5.56 \%$ weren't working. With regard to years of experience, $5.56 \%$ had never worked, $72.92 \%$ had worked between 1 - 10 years, and $18.01 \%$ had worked between $11-20$ years, while $3.47 \%$ had worked for 21 years and above. 
The results revealed that learning goal orientation is significantly correlated with leadership development, $\mathrm{r}(288)=.423, \mathrm{p}<.001$, shown in table 1 below.

Table 1: Correlation between Learning Goal Orientation and Leadership Development

\begin{tabular}{llll}
\hline & & Learning Goal Orientation (LGO) & Leadership Development (LD) \\
\hline LGO & Pearson Correlation & 1 & $.423^{* *}$ \\
\cline { 2 - 4 } & Sig. (2-tailed) & .000 \\
\cline { 2 - 4 } & $\mathrm{N}$ & 288 & 288 \\
\hline LD & Pearson Correlation & $.423^{* *}$ & 1 \\
\cline { 2 - 4 } & Sig. (2-tailed) & .000 & 288 \\
\cline { 2 - 4 } & $\mathrm{N}$ & 288 & \\
\hline
\end{tabular}

One-Way ANOVA revealed a significant difference in the mean scores between the respondents with low and high learning goal orientation, $\mathrm{F}(1,286)=43.952, \mathrm{p}<.001$, as shown in table 2 below.

Table 2: ANOVA of Leadership Development with Respect to Learning Goal Orientation

\begin{tabular}{llllll}
\hline & Sum of Squares & df & Mean Square & F & Sig. \\
\hline Between Groups & 33.593 & 1 & 33.593 & 43.952 & .000 \\
\hline Within Groups & 218.593 & 286 & .764 & & \\
\hline Total & 252.186 & 287 & & &
\end{tabular}

Additionally, the results of One-Way ANOVA showed that respondents' learning goal orientation mean scores with respect to employment status, positions and industries are statistically significant, $\mathrm{F}(2,285)=4.000, \mathrm{p}=.019, \mathrm{~F}(4,283)=2.764, \mathrm{p}=.028$, $\mathrm{F}(3,284)=2.960, \mathrm{p}=.033$ respectively, while respondents' learning goal orientation mean scores with respect to age, gender and years of experience are statistically insignificant. The results of regression of leadership development against learning goal orientation revealed a significant model $F(1,286)=62.346, \mathrm{p}<001$, with a 22 of .179, as shown in table 3 and table 4 .

Table 3: ANOVA for Regression of LD against LGO

\begin{tabular}{lllllll}
\hline Model & Sum of Squares & df & Mean Square & F & Sig. \\
\hline $\mathbf{1}$ & Regression & 45.135 & 1 & 45.135 & 62.346 & $.000 \mathrm{~b}$ \\
\cline { 2 - 8 } & Residual & 207.051 & 286 & .724 & & \\
\cline { 2 - 7 } & Total & 252.186 & 287 & & & \\
\hline
\end{tabular}

a. Dependent Variable: LD

b. Predictors: (Constant), LGO

Table 4: Model Summary for Regression of LD against LGO

\begin{tabular}{llllll}
\hline Model & R & R Square & Adjusted R Square & Std. Error of the Estimate & Durbin-Watson \\
\hline $\mathbf{1}$ & $.423 \mathrm{a}$ & .179 & .176 & .85085 & 1.754 \\
\hline
\end{tabular}

a. Predictors: (Constant), LGO

b. Dependent Variable: LD

Learning goal orientation is a significant predictor of leadership development, $(\beta=.537, \mathrm{t}(286)=7.896, \mathrm{p}<.001)$, as shown in table 5. Given that $\mathrm{p}<.05$, the null hypothesis was rejected, while the alternative hypothesis was accepted, that is, learning goal orientation has a significant effect on leadership development.

Table 5: Coefficient for Regression of LD against LGO

\begin{tabular}{|c|c|c|c|c|c|c|}
\hline \multirow[t]{2}{*}{ Model } & \multicolumn{3}{|c|}{ Unstandardized Coefficients } & \multirow{2}{*}{$\begin{array}{l}\text { Standardized Coefficients } \\
\text { Beta }\end{array}$} & \multirow[t]{2}{*}{$\mathbf{t}$} & \multirow[t]{2}{*}{ Sig. } \\
\hline & B & & Std. Error & & & \\
\hline \multirow[t]{2}{*}{1} & (Constant) & 1.916 & .152 & & 12.581 & .000 \\
\hline & LGO & .537 & .068 & .423 & 7.896 & .000 \\
\hline
\end{tabular}


Dependent Variable: LD

\section{Discussion}

The present study sought to establish whether learning goal orientation had a significant effect on leadership development. Correlation analysis, One-Way ANOVA and regression analysis of leadership development with respect to learning goal orientation were performed in furtherance of the study objective. The correlation analysis revealed that learning goal orientation is significantly correlated with leadership development, $\mathrm{r}(288)=.423, \mathrm{p}<.001$. The study indicates that learning goal orientation is related to leadership development, that is, the two variables vary together. The results mirror correlations between learning goal orientation and constructs similar to learning leadership (leadership development), like training satisfaction, training transfers, information acquisition and asking feedback (Harris, Chung, Hutchins, \& Chiaburu, 2014; Kunst, Woerkom \& Poell, 2017).

The One-Way ANOVA results revealed that there was a significant difference in leadership development mean scores between respondents with low learning goal orientation scores and respondents with high learning goal orientation scores, where $\mathrm{F}(1,286)=$ 43.952, $\mathrm{p}<.001$. The findings indicated that respondents with low learning goal orientation scores also had low leadership development scores and vice versa, these outcomes are similar to Kunst et al.'s (2017) findings. According to Montecinos et al. (2014), learning goal orientation propels individuals to develop skills and gain knowledge which may explain why respondents with high learning goal orientation scores also have high scores in leadership development. The findings support DeGeest \& Brown's (2011), assertions that high learning goal orientation influence better development of leadership skills and acquisition of knowledge, while low learning goal orientation impede leadership development. Also Tan, Au, Cooper-Thomas and Aw (2016) observed that learning goal orientation affects information seeking behaviors.

The results of the regression analysis showed that learning goal orientation significantly predicted leadership development, $\mathrm{F}(1,286)$ $=62.346, \mathrm{p}<001$, with a R2 of .179. The findings indicate that learning goal orientation scores forecast the leadership development scores. The outcomes also echoes the results of similar studies in which learning goal significantly predicted creativity, training satisfaction, training transfer, innovative performance, students' psychological wellbeing and students' mathematics achievements (Huang \& Luthans, 2015; Harris et al., 2014; Lu, Lin \& Leung, 2012; Sosik, Chun \& Koul, 2017; Lin et al., 2009). The results indicate that learning goal orientation level is a good indicator of how learners will perform in leadership development.

The significant effect of learning goal orientation on leadership development, underlines its importance in developing leaders. Given the importance of learning goal orientation, leadership developer may seek to understand the relationship of learning goal orientation with different demographical factors. This may inform the approaches that may be adopted in boosting learning goal orientation. One-Way ANOVA revealed that the difference in learning goal orientation mean scores among different age groups was not significant, $F(3,284)=1.762, p=.155$. The results indicate that the participants' age may not be an indicator how they will score in learning goal orientation. The outcomes are dissimilar to McCollum and Kajs' (2007) findings who argued that age affected learning goal orientation scores, however, their conclusions were based only on descriptive analysis which is not the case in this study. Also the findings of the study showed that respondents' leaning goal orientation mean scores for different genders were not significantly different, $\mathrm{F}(1,287)=.083, \mathrm{p}=.774$. The discoveries indicate programs intended to boost people's learning goal orientation scores may not pay much attention to the gender of the participants.

However, leaning goal mean scores of respondents with different employment status were significantly different, $\mathrm{F}(2,285)=4.000$, $\mathrm{p}=.019$. Respondents who were employed at the time of the study registered higher scores in learning goal orientation than their counterparts who were not employed. Learning goal orientation mean scores of the three categories of employment status also showed that respondents who had never been employed/self-employed had the lowest mean score. The findings indicate that employment help in boosting one's learning goal orientation. The outcomes are not surprising because employment in most cases demands that employees exert more effort in order to meet the organizational goals, while it offers challenging tasks to employees. These activities are critical ingredients for improving one's learning goal orientation. The challenge for leadership developers is that some of the participants in leadership development may have not been employed before, hence they may have low learning goal orientation. The developers have to help such participants to improve their learning goal orientation before they undertake additional leadership developmental activities.

Further, the findings of One-Way ANOVA revealed that respondents' learning goal orientation mean scores for different positions are significantly different, $\mathrm{F}(4,283)=2.764, \mathrm{p}=.028$ ). The results indicate that the higher one's position in the organization, the higher the score in learning goal orientation. The outcomes may be attributable to the fact that as one rises in position, their responsibilities also increase, Zenger and Folkman (2014), hence much is required of them, which may lead them to doubling of their effort. They are also exposed to more stretch goals and challenging opportunities; these experiences go a long way in improving one's learning goal orientation. Leadership developers, who may be dealing with individuals in lower positions, have to boost their learning goal orientation before exposing them to more developmental initiatives.

In addition, the findings of the One-Way ANOVA showed that respondents' learning goal orientations mean scores in different industries were significantly different, $F(3,284)=2.960, p=.033$. The results agree with Kunst et al.'s, (2017) assertions. Leadership development professionals should pay attention to the differing levels of learning goal orientation in different industries, so that they can deploy the right developmental initiatives to the right group of participants at the right time. 
Finally, the results of the One-way ANOVA revealed that learning goal orientation mean scores of respondents with different years of experience were not significantly different, $F(5,2820=1.772, p=.119$. Although, Kunst et al. (2017) argued that the length of one's experience was related to their learning goal orientation, this study has established that the difference in learning goal means scores of different work experience groups is not significant. Leadership development professionals may not have to take into consideration participants' years of experience with regard to improving their learning goal orientation. Given that both industry and position affects learning goal orientation significantly but the years of experience do not; it may indicate that it is not the years people has worked that matter in boosting their learning goal orientation, but type of experiences that people have had during that time.

\section{Conclusions}

The study revealed that learning goal orientation significantly affects leadership development. The study indicates that individuals with high learning goal orientation scores also obtain high scores in leadership development, while individuals with low learning goal orientation scores also obtain low scores in leadership development. Leadership development is characterized by numerous challenging tasks, from understanding the numerous leadership theories, practical assignments to carrying out group and individual assignments. Therefore, it takes individuals who are open and motivated by challenging tasks to succeed in leadership development. Individuals with high learning goal orientation apply extra effort in their leadership studies and they are open to challenging tasks. They are also more likely to engage in leadership self-development, because they are already motivated to learn. Finally, the employment status, position and industry of the leadership development participants are critical factors in boosting participants' learning goal orientation, while age, gender and years of experience are not essential factors. Given that high learning goal orientation helps leadership development participants to benefit fully from leadership training, the study results imply that it is of paramount importance for organizations and leadership developers to ensure that leaders acquire high learning goal orientation during leadership development. The results also imply that leaders who are undergoing leadership self-development should also seek to improve their learning goal orientation which will go a long way in helping them gain most from leadership self-development. High learning orientation should is a precursor for leadership development. The study recommends that it is replicated in other parts of the world, in order to establish the applicability of the study findings globally.

\section{References}

Aiken, L. (1997). Questionnaires and inventories. New York, NY: John Wiley \& Sons.

Che-Ha, N., Mavondo, F., \& Mohd-Said, S. (2014). Performance or learning goal orientation: Implications for business performance. Journal of Business Research, Vol. 67, pp. 2811 - 2820. https://doi.org/10.1016/j.jbusres.2012.08.002

DDI (2015). Ready-now leaders: 25 findings to meet tomorrow's business challenges - the global leadership forecast $2014-2015$. https://www.ddiworld.com/DDI/media/trend-research/global-leadership-forecast-2014-2015_tr_ddi.pdf

DeGeest, D., \& Brown, K. (2011). The role of goal orientation in leadership development programs. Human Resources Development Quarterly, Vol. 22, No. 2, pp. 157 - 176. https://doi.org/10.1002/hrdq.20072

Deloitte (2014). Global human capital trends: Engaging the 21st-century workforce. https://www2.deloitte.com/content/dam/Deloitte/ar/Documents/human-capital/arg_hc_global-human-capital-trends2014_09062014\%20(1).pdf

Dweck, C. (1986). Motivational processes affecting learning. American Psychologist, Vol. 41, No. 10, pp. 1040 - 1048. https://doi.org/10.1037/0003-066X.41.10.1040

Eckert, R., Isaakyan, S., \& Mulhern, W. (2014). The effectiveness of the leadership development programme in Europe: An evaluation report. Greensboro, NC: Center for Creative Leadership.

Harris, T., Chung, W., Hutchins, H., \& Chiaburu, D. (2014). Do trainer style and learner orientation predict training outcomes? Journal of workplace learning, Vol. 26, No. 5, pp. 331 - 344. http://dx.doi.org/10.1108/JWL-05-2013-0031

Huang, L., \& Luthans, F. (2015). Toward better understanding of the learning goal orientation-creativity relationship: The role of positive psychological capital. Applied Psychology: An International Review, Vol. 64, No. 2, pp. $444-472$. https://doi.org/10.1111/apps. 12028

Kim, S. (2007). Learning goal orientation, formal mentoring, and leadership competence in HRD: A conceptual model. Journal of European Industrial Training, Vol. 31, No. 3, pp. 181 - 194. https://doi.org/10.1108/03090590710739269

Kunst, E., Woerkom, M., \& Poell, R. (2017). Teachers' goal orientation profiles and participation in professional development activities. Vocations and Learning, Vol. 11, No. 1, pp. 91 - 111. https://doi.org/10.1007/s12186-017-9182-y

Leslie, J. (2015). The leadership gap what you need, and still don't have, when it comes to leadership talent. Greensboro, NC: Center for Creative Leadership.

Lu, L., Lin, X., \& Leung, K. (2012). Goal orientation and innovative performance: The mediating roles of knowledge sharing and perceived autonomy. Journal of Applied Social Psychology, Vol. 42, No. 1, pp. E180-E197. https://doi.org/10.1111/j.15591816.2012.01018.x

McCollum, D., \& Kajs, L., (2007). Applying goal orientation theory in exploration student motivations in the domain of educational leadership. Education Research Quarterly, Vol. 31, No. 1, pp. 45-59. https://files.eric.ed.gov/fulltext/EJ792868.pdf

Montecinos, C., Madrid, R., Fernández, M., \& Ahumada, L. (2014). A goal orientation analysis of teachers' motivations to participate in the school self-assessment processes of a quality assurance system in Chile. Educ Asse Eval Acc, Vol. 26, pp. 24 - 261. 
https://doi.org/10.1007/s11092-014-9190-5

Monyoncho, R. (2014). The leadership dilemma: An African perspective - Confronting Africa's governance challenges in 21st century. Nairobi, KE: Aura Publishers

Muteswa, R. (2016). Qualities of a good leader and the benefits of good leadership to an organization: A conceptual study. European Journal of Business and Management, $\quad$ Vol. $8, \quad$ No. $\quad 24, \quad$ pp. $\quad 135 \quad-\quad 140$. https://iiste.org/Journals/index.php/EJBM/article/viewFile/32472/33363

Njue, N., Waiganjo, E., \& Kihoro, J. (2016). Influence of coaching as a leadership practice on the performance of microfinance institutions in Kenya. International Journal of Academic Research in Business and Social Sciences, Vol. 6, No. 10, pp. 206 -217 .

http://hrmars.com/hrmars_papers/Influence_of_Leadership_Empowerment_as_a_Leadership_Development_Practice_on_t he_Performance_of_Microfinance_Institutions_in_Kenya.pdf

Petrie, N. (2014). Future trends in leadership development. Greensboro, NC: Center for Creative Leadership.

Sosik, J, Chun, J., \& Koul, R. (2017). Relationships between psychological well-being of Thai college students, goal orientations, and gender. Psychology in the Schools. wileyonlinelibrary.com/journal/pits, DOI: 10.1002/pits.22024

Souba, W., \& Souba, M. (2018). Leaders as distinction generators. Open Journal of Leadership, Vol. 7, No. 2 , pp. 145 - 154. https://10.4236/oj1.2018.72008

Tan, K., Au, A., Cooper-Thomas, H., \& Aw, S. (2016). The effect of learning goal orientation and communal goal strivings on newcomer proactive behaviors and learning. Journal of Occupational and Organizational Psychology, Vol. 89, pp. 420445. https://doi.org/10.1111/joop.12134

Volz-Peacock, M., Carson, B., \& Marquardt, M. (2016). Action learning and leadership development. Advances in Developing Human Resources, Vol. 18, No. 3, pp. 318 -333. https://doi.org/10.1177/1523422316645884

Zenger, J., \& Folkman, J. (2014). The skills leaders need at every level. Harvard Business Review. Retrieved on 19/08/2018, from https://hbr.org/2014/07/the-skills-leaders-need-at-every-level 